\title{
Koncepcyjne założenia oceny oddziaływania przedsiębiorstw na gospodarkę
}

\section{Tomasz Geodecki*}

\begin{abstract}
Streszczenie: W kontekście dyskusji o pułapce średniego dochodu i promowania rodzimych przedsiębiorstw, w artykule zaproponowano metodę mającą na celu identyfikację i kalkulację korzyści przynoszonych przez przedsiębiorstwo krajowej gospodarce. Przyjęta metoda badawcza polega na zidentyfikowaniu kategorii składających się na wartość dodaną kreowaną przez przedsiębiorstwo, a następnie na przetestowaniu tak skonstruowanego narzędzia oceny z wykorzystaniem sprawozdań finansowych trzech spółek giełdowych. Punktacja przyznawana przedsiębiorstwu oparta jest na sumie wynagrodzeń pracy, kapitału i podatków, tj. wynagrodzeń i innych świadczeń na rzecz pracowników, akumulacji kapitału oraz zysku podzielonego pomiędzy rezydentów krajowych, jak również podatku dochodowego od osób prawnych zapłaconego przez przedsiębiorstwo. W celu uwzględnienia skali działalności przedsiębiorstwa, a także dla oceny efektywności wykorzystania czynników wytwórczych, podzielono sumę tych elementów przez wartość aktywów przedsiębiorstwa. Wnioski obejmują potwierdzenie zasadności abstrahowania w ocenie od narodowości właściciela ocenianego przedsiębiorstwa, rozważania nad adekwatnością metody do rzeczywistości gospodarczej oraz ewentualnym włączeniem do oceny dodatkowych kategorii z zakresu społecznego oddziaływania przedsiębiorstw.
\end{abstract}

Słowa kluczowe: oddziaływanie przedsiębiorstwa na gospodarkę, korzyści społeczne, wartość dodana, zysk, podatki, wynagrodzenia.

\section{Wprowadzenie $^{1}$}

Celem artykułu jest, po pierwsze, dokonanie wyboru metody oceny oddziaływania przedsiębiorstwa na gospodarkę krajową zgodnej z dwoma kryteriami: adekwatności i prostoty pomiaru oraz, po drugie, przedstawienie metody oceny przedsiębiorstw obejmującej skłonność do dzielenia się wytworzoną wartością dodaną z pracownikami i państwem oraz do akumulacji kapitału. Te elementy mogą być podstawą do oceny społecznej odpowiedzial-

Publikacja została przygotowana w projekcie „Ekonomiczna analiza marginalizacji własności w gospodarce" nr: 056/ WGAP-KAP/01/2018/S/8056, dofinansowanym z dotacji Ministerstwa Nauki i Szkolnictwa Wyższego dla Wydziału Gospodarki i Administracji Publicznej Uniwersytetu Ekonomicznego w Krakowie na utrzymanie potencjału badawczego. ności przedsiębiorcy w sytuacji, gdy przedsiębiorcy wykorzystują możliwości płacenia podatków za granicą oraz nakłonienia pracowników do rezygnacji z umowy o pracę. W artykule zaproponowano prosty mechanizm identyfikacji takich przedsiębiorstw, które korzystnie oddziałują na gospodarkę, i które w zamian mogłyby liczyć na przychylność konsumentów w sklepach czy preferencje w dostępie do za-

\footnotetext{
* Tomasz Geodecki

Katedra Administracji Publicznej Uniwersytet Ekonomiczny w Krakowie ul. Rakowicka 16, 31-510 Kraków e-mail: tomasz.geodecki@uek.krakow.pl
} 
mówień publicznych ${ }^{2}$. Kolejno zaprezentowano wprowadzenie teoretyczne, przedstawiając możliwe do zmierzenia zakresy oddziaływania przedsiębiorstwa, kryteria wyboru właściwego poziomu i prostoty pomiaru w oparciu o dostępność danych. Kolejny punkt obejmuje prezentację wybranej metody pomiaru z wyodrębnieniem jej trzech komponentów. W punkcie trzecim przedstawiono zastosowanie oceny do trzech spółek giełdowych, a w punkcie czwartym wnioski z wypróbowania metody do oceny oddziaływania firm obejmujące także namysł nad jej ewentualnymi uzupełnieniami.

\section{Wybór przedmiotu i metody oceny oddziaływania przedsiębiorstwa na gospodarkę}

\subsection{Wpływ przedsiębiorstwa na otoczenie gospodarcze - przegląd ujęć teoretycznych}

Wyróżnić można trzy zasadnicze grupy ocen wpływu przedsiębiorstw na otoczenie gospodarcze w zależności od przyjętego zakresu oddziaływania i przedmiotu badania. Pierwsza grupa obejmuje najszerszy zakres oddziaływania, bazując na spostrzeżeniu, że wpływ przedsiębiorstwa na krajową gospodarkę jest większy niż suma jego wydatków na płace, nabycie dóbr czy inwestycje. Wszak złotówka wydana przez podmiot jest wydatkowana ponownie przez pracowników lub dostawców, zatem obok bezpośredniego oddziaływania przedsiębiorstwa, poprzez jego wydatki, wyróżnia się efekty pośrednie i indukowane. Dla ich zidentyfikowania stosuje się tablice przepływów międzygałęziowych skonstruowane przez Leontiefa [1941], pozwalające zmierzyć siłę oddziaływania w zależności od segmentu gospodarki. Zastosowania metod oddziaływania projektów z ich wykorzystaniem prezentują np. Bess i Ambargis [2011] czy Hamilton z zespołem [1991]. Użytecznym prze-

Metoda miała mieć od początku stosowany, a nie tylko teoretyczny charakter - jako uzupełnienie dla aplikacji POLA, o której więcej w treści artykułu. wodnikiem dla podejmujących analizy tego rodzaju jest podręcznik Millera i Blaira [2009].

Druga grupa metod opiera się na bezpośrednim oddziaływaniu gospodarczym. Dokonując ich przeglądu B. Weisbrod i G. Weisbrod [1997] dzielą te metody ze względu na zakres oddziaływania, na obejmujące:

a) obroty gospodarcze (przychody ze sprzedaży),

b) wartość dodaną,

c) zagregowany dochód osobisty,

d) zatrudnienie ogółem,

e) zwiększenie wartości nieruchomości.

Z przedstawionej hierarchii najbardziej adekwatnym do oceny oddziaływania wydaje się poziom drugi. Choć to nieco węższa ocena niż poziom pierwszy, to jednak obejmuje nie tyle skalę działalności, ile adekwatność efektów gospodarczych do owej skali i jej rentowność. Przykładowe zastosowania analizy tworzenia wartości dodanej przez sektory gospodarek narodowych znaleźć można u Białowąsa [2016], a przeniesiona na poziom przedsiębiorstw powraca współcześnie w dyskusjach o ekonomicznej wartości dodanej [patrz np. Wawiernia, 2013; Nowicki, 2018]. W szerszym znaczeniu o metodach raportowania wartości dodanej przez przedsiębiorstwa pisze S. Lorenc [2016], podkreślając postulat tworzenia „Czwartego sprawozdania finansowego" dla wykazania zaspokojenia potrzeb interesariuszy spółki.

Do trzeciej grupy ocen zaliczyć można autodiagnozę oddziaływania na otoczenie dokonywaną przez same przedsiębiorstwa, bazującą na unikalnej wiedzy, generowanej wewnątrz firmy i nie udostępnianej na zewnątrz. Interesującej próby szerokiego ujęcia wpływu przedsiębiorstwa i prezentacji narzędzi analizy dokonał zespół ekspertów WBCSD [2013]. Podobny charakter ma narzędzie ESometr, pozwalające przedsiębiorstwom ekonomii społecznej ocenić się na tle innych, podobnych, bazując na elementach społecznej wartości dodanej, takich jak: zatrudnienie, inwestycje w kapitał ludzki, reintegracja zawodowa i społeczna, kapitał 
społeczny i wpływ na społeczność lokalną [Głowacki, Jelonek, 2013].

Z alternatywnych podejść do oceny oddziaływania przedsiębiorstwa na gospodarkę krajową, łączących kilka metod, warto wspomnieć o uruchomionej w 2015 r. aplikacji POLA na telefony komórkowe, umożliwiającej i wybieranie przy zakupach tych produktów, które mają wysoki udział polskiego kapitału (35\% punktów), są zarejestrowane $(10 \%)$ i zatrudniają (15\%) w Polsce, ponoszą nakłady na B+R (15\%) i nie są częścią zagranicznych koncernów (10\%). Rezygnacja z zastosowania takiego podejścia w proponowanej ocenie wynika $z$ braku tożsamości polskiej własności kapitału z korzyściami społecznymi, która ujawnia się w przypadkach, gdy np. spółka nie płaci podatku w kraju lub przenosi działalność za granicę.

\subsection{Kryteria wyboru metod oceny}

Wybór metody oceny korzyści związanych $z$ funkcjonowaniem przedsiębiorstwa $i$ jego wpływem na otoczenie gospodarcze jest kompromisem pomiędzy tym, co powinno zostać zmierzone a tym, co może być zmierzone efektywnie, tj. z uwzględnieniem dostępności danych i kosztu dotarcia do nich. Pierwsze kryterium zawęża wybór do takich metod, które $\mathrm{z}$ jednej strony pozwalają wskazać, w jakim stopniu przedsiębiorca generuje korzyści dla lokalnej gospodarki, z drugiej zaś strony skoro oceniane są przedsiębiorstwa - ocena powinna obejmować kwestie leżące w sferze wyboru przedsiębiorcy. Natomiast drugie kryterium bazuje na ocenie możliwości dotarcia do danych przez zewnętrznego analityka.

Postulat zgodności przedmiotu pomiaru z przyjętymi założeniami, w największym stopniu spełnia propozycja pomiaru wartości dodanej. Po pierwsze bowiem nie obejmuje ona efektów gospodarczych, które w znaczącej mierze pozostają poza sferą oddziaływania przedsiębiorcy, ponieważ są specyficzne dla gałęzi. Włączając do analizy także efekty pośrednie i indukowane oceniano by wpływ przedsiębiorstwa na inne elementy systemu gospodarczego, który jednak leży poza jego możliwością kształtowania. Intencją skonstruowania proponowanej metody pozostaje ocena skłonności przedsiębiorców do dzielenia się wytworzoną wartością dodaną z pracownikami i krajową gospodarką. Bowiem w obliczu możliwości przenoszenia pracowników poza relacje regulowane kodeksem pracy oraz relatywnie łatwego przenoszenia zobowiązań podatkowych za granicę, ten podstawowy zakres odpowiedzialności przedsiębiorcy za wspólnotę jawi się jako pierwotny i najważniejszy w stosunku do szerzej rozumianego oddziaływania społecznego. Po drugie natomiast, odrzucono metody bazujące na samoocenie przedsiębiorców. Dla możliwości dokonania oceny zewnętrznej potrzebne są dane, które spółki ujawniają ze względu na obowiązek sprawozdawczy.

Przedmiotem pomiaru będzie zatem wartość dodana tworzona przez przedsiębiorstwo oraz jej trzy podstawowe komponenty: 1) wynagrodzenia (i świadczenia na rzecz pracowników), 2) dochody z kapitału oraz 3) płacone podatki. Umożliwiają one zaspokojenie potrzeb indywidualnych i zbiorowych, a utrzymująca się rentowność przedsiębiorstw stanowiąca podstawę do oceny ich konkurencyjności pozytywnie wpływa na otoczenie gospodarcze. Co istotne, sprawozdania finansowe przedsiębiorstw w wielu przypadkach udostępniane są publicznie i pozwalają uchwycić i zmierzyć te kategorie. Poniżej zastosowano metodę do oceny trzech spółek giełdowych obowiązkowo publikujących sprawozdania finansowe. Metoda ta może być potencjalnie użyteczna dla przedsiębiorstw, gdyż użyta może być np. jako element budowy wizerunku firmy czy stosowana przy preferencjach w zamówieniach publicznych.

Warto przy tym zauważyć, że zastosowanie jednej metody oceny do całkowicie odmiennych modeli biznesowych obarczone może być mankamentem ograniczonej porównywalności. Proponowana metoda jest więc swego rodzaju rusztowaniem, które może zostać uzupełnione dodatkowymi aspektami wpływu 
na otoczenie, uwzględniającymi specyfikę różnorodnych form prawnych i branż gospodarki.

\section{Konceptualne ramy metody oceny oddziaływania przedsiębiorstw na gospodarkę w zakresie tworzenia wartości dodanej}

\subsection{Rachunki narodowe jako to teoretyczne proponowanej metody oceny}

Skalę wytworzonej w gospodarce wartości dodanej można ująć jako sumę dochodów właścicieli czynników produkcji: każda cząstka wartości dóbr finalnych jest albo wynagrodzeniem pracy, albo kapitału. Ponieważ sprawozdania finansowe przedsiębiorstw zawierają informację o zysku oraz wynagrodzeniu za pracę, można oprzeć metodę oceny na elementach, na które dzieli się wartość dodana wytworzona w firmie, a więc na sumie dochodów właścicieli czynników produkcji, czyli od strony dochodowej (income approach). W ten sposób można obliczyć dochody zaspokajające potrzeby społeczne jako sumę wynagrodzeń pracowników i zysków właścicieli kapitału zaspokajających potrzeby indywidualne oraz podatków zaspokajających potrzeby zbiorowe ${ }^{3}$.

Pewną komplikacją jest włączenie do analizy zagranicy, gdyż dochody czynników produkcji mogą być transferowane za granicę. Odróżnić więc należy produkt krajowy brutto (PKB) od produktu narodowego brutto (PNB), który powstaje po dodaniu do PKB dochodów krajowych czynników produkcji uzyskanych za granicą i po odjęciu dochodów zagranicznych czynników wynagradzanych w kraju. Proponowana metoda obejmuje dochody bliższe kate-

Współcześnie stosowaną koncepcję wykorzystania oszacowań skali produkcji do pomiaru dobrobytu zaproponował Kuznets w 1934 r. O metodach konstruowania rachunków narodowych piszą autorzy popularnych podręczników do makroekonomii, m.in. Begg z zespołem [2014] czy Blanchard [2011]. Bardziej szczegółową metodologię ich tworzenia i interpretacji Czytelnik znajdzie np. w podręczniku OECD autorstwa Lequillera i Blades'a [2006]. gorii PNB, co można nazwać krajową wartością dodaną. Jej aproksymacją będzie suma:

1. wynagrodzeń pracowników (tu także PIT) wraz ze świadczeniami na rzecz pracowników,

2. zysku właścicieli przedsiębiorstwa (wraz z PIT od wynagrodzenia kapitału),

3. podatku od osób prawnych (CIT) płaconego przez przedsiębiorstwo w kraju.

Wybrane elementy są zawarte w sprawozdaniach finansowych spółek i w zasadzie każde większe przedsiębiorstwo jest w stanie łatwo je wskazać.

\subsection{Odniesienie uzyskiwanych dochodów do skali działalności gospodarczej}

Miarą efektywności gospodarowania jest rezultat proporcjonalny do wielkości zasobów, które się użytkuje. Prowadzi to do analizy wynagrodzeń, zysków i podatków w relacji do liczby pracujących lub wykorzystywanych aktywów. Przyjęcie odniesienia do liczby pracujących, choć kontrowersyjne, gdyż często traktuje się pracę jako dobro, które należy pomnażać, jest jednak właściwe z perspektywy rzeczywistych motywacji ludzkich. Praca jest środkiem do celu, jakim jest zaspokojenie potrzeb, zatem nie należy dążyć do maksymalizowania zatrudnienia, gdyż oszczędne wykorzystanie zasobów daje większą wartość dodaną, pozwalającą następnie zaspokajać potrzeby. Wskaźnik liczby zatrudnionych jako punkt odniesienia ma jednak wadę: $w$ krajach, w których zyskuje na popularności outsourcing oraz w gospodarkach, w których prawo dopuszcza wieloletnie zatrudnienie pracowników na podstawie umów cywilno-prawnych, mniejszy będzie odsetek zatrudnionych w tradycyjnej formie umowy o pracę.

Alternatywnie można przyjąć odniesienie do wartości zaangażowanego kapitału, co jest zabiegiem stosowanym przy analizie rentowności i interpretuje się jako zdolność do wygenerowania odpowiednich zysków w relacji do aktywów lub kapitału własnego. Miara ta ma także mankamenty, np. premiowane byłyby 
przedsiębiorstwa o niskim poziomie technicznego uzbrojeniu pracy. Przedsiębiorstwa przemysłowe muszą dysponować odpowiednim i kosztownym parkiem maszynowym, podczas gdy część firm usługowych może nie dysponować dużym majątkiem i świadczyć usługi wynajmując go. Z tego względu porównania międzysektorowe mają tu ograniczone zastosowanie i na większej próbie przedsiębiorstw należałoby dopiero rozpoznać referencyjne wartości. Proponuje się przyjąć jako wyjściowy punkt odniesienia wartość aktywów wykazywanych w sprawozdaniu finansowym na dzień 31 grudnia roku poprzedzającego rok oceny.

\subsection{Podstawowe elementy metody oceny przedsiębiorstw}

Wynagrodzenia: proponowany wskaźnik ujmuje wynagrodzenia wypłacone w danym roku powiększone o świadczenia na rzecz pracowników. Problemem dla obliczeń może być relatywnie duża skala outsourcingu polegającego na zamianie umowy o pracę z dotychczasowym pracownikiem firmy na relację dwóch podmiotów gospodarczych. Nie ma jednak możliwości odróżnienia usług obcych od świadczonych przez dawnych pracowników.

Podatek dochodowy od osób prawnych: im większy jest podatek dochodowy, w tym większym stopniu pozwala na zaspokojenie potrzeb zbiorowych (a w ostateczności także indywidualnych). Miara wpłaconego CIT (podatek bieżący) pozwala na zignorowanie wydarzeń zmniejszających zysk. Na przykład przedsiębiorstwo nabywające od zagranicznej spółki-matki licencję po zawyżonych kosztach, zmniejszy zysk i CIT, a zatem uzyska mniej punktów. Dopracowania wymagałoby objęcie oceną spółek osobowych, które nie płacą CIT ${ }^{4}$.

\footnotetext{
Podatków pośrednich nie włączono do oceny, ponieważ obciążają one konsumentów, a zatem firma jest swego rodzaju pośrednikiem pomiędzy konsumentem i Skarbem Państwa - a w sytuacji zróżnicowania stawek VAT nie może zostać on uznany za proporcjonalny do wartości dodanej. Do korzyści generowanych przez firmę należałoby zaliczyć niektóre inne podatki i opłaty, np. podatek od nieruchomo-
}

Wynagrodzenie kapitału: dochody z kapitału uzyskują nie tylko wielcy kapitaliści oraz akcjonariusze i udziałowcy spółek, ale także pracownicy oszczędzający na swoją emeryturę za pośrednictwem funduszy emerytalnych. W dobie globalizacji coraz częściej udziałowcami i akcjonariuszami spółek krajowych są podmioty zagraniczne. Dywidenda wypłacana inwestorom jest wynagrodzeniem poniesionych nakładów i podjętego ryzyka. Tym niemniej, z perspektywy kraju goszczącego, należy docenić inwestorów za korzyści, które przynoszą gospodarce krajowej. Posiadane dane ze sprawozdań spółek i rejestrów sądowych pozwalają w przybliżeniu ocenić, czy zysk realizowany przez przedsiębiorstwo zasila gospodarkę krajową, czy transferowany jest za granicę. W tym celu rozróżnić można trzy podstawowe sytuacje: a) zysk pozostaje niewypłacony w formie dywidendy i zatrzymany w spółce powiększając jej kapitał i zdolności inwestycyjne - wtedy mogą powiększyć przyszłe wynagrodzenia pracowników i dochody spółki, a zatem i płacone podatki;

b) wypłacane $w$ formie dywidendy rezydentom krajowym bezpośrednio lub za pośrednictwem spółek z siedzibą w kraju, albo też reinwestowane $w$ takiej spółce krajowej - w obu przypadkach zaspokoją albo potrzeby konsumpcyjne krajowych rezydentów (gdy trafiają do obrotu w krajowej gospodarce oraz są opodatkowane podatkiem PIT) albo potrzeby inwestycyjne spółek krajowych lub krajowych rezydentów (wówczas także ich większość trafia do krajowej gospodarki; są też źródłem przyszłego zysku);

c) wypłacane $w$ formie dywidendy osobom prawnym mającym siedzibę za granicą lub osobom fizycznym niebędącym rezy-

\footnotetext{
ści. Niestety, w pozycji podatki i opłaty ujęte są także podatki akcyzowe, co premiowałoby spółki obracające towarami akcyzowymi. Dodatkowo opłaty mogą być rekompensatą za korzystanie ze środowiska, ponieważ wpłata ta nie jest korzyścią netto dla społeczeństwa, lecz ekwiwalentem za poczynione szkody lub korzystanie ze środowiska.
} 
dentami krajowymi - nie są opodatkowane w kraju ani nie zaspokajają potrzeb rezydentów krajowych ${ }^{5}$.

Sytuacja a) jest korzystna z punktu widzenia przyszłych spodziewanych wynagrodzeń zysków i podatków. Proponuje się zatem włączyć do oceny akumulację kapitału definiowaną jako różnica między osiągniętym zyskiem netto i wypłaconą dywidendą. W przypadku niewypłacenia przez spółkę dywidendy przyznano przedsiębiorstwu punktację proporcjonalną do akumulacji kapitału6. W sytuacji b) zysk przypada rezydentom krajowym i zaspokaja ich potrzeby - tę sytuację potraktować należy podobnie jak wypłatę wynagrodzeń i przyznać punktację proporcjonalnie do wypłaconej dywidendy. W przypadku osób prawnych z siedzibą w kraju zweryfikować należy ich strukturę własnościową i przyznać punktację proporcjonalnie do udziału w niej krajowych rezydentów podatkowych lub spółek z siedzibą w Polsce ${ }^{7}$. Może zdarzyć się, że spółka z siedzibą w kraju jest częścią międzynarodowej korporacji - wtedy należy zweryfikować strukturę własnościową spółki-matki. Natomiast w sytuacji c) zyski z reguły transferowane są za granicę, a właścicielami takich spółek zagra-

\footnotetext{
Zwalnia się od podatku dochodowego dochody (przychody) z dywidend, jeżeli spełnione są warunki, że spółka otrzymująca dywidendę posiada bezpośrednio nie mniej niż 10\% udziałów (akcji) w kapitale spółki wypłacającej (dla Szwajcarii co najmniej 25\%), a posiadanie udziałów ma miejsce nieprzerwanie przez okres dwóch lat (jednak możliwe jest dopełnienie tego warunku w przyszłości) oraz że spółka otrzymująca dywidendę nie korzysta ze zwolnienia z opodatkowania podatkiem dochodowym od całości swoich dochodów, bez względu na źródło ich osiągania. Ponieważ umowy międzypaństwowe o unikaniu podwójnego opodatkowania często przewidują preferencyjne stawki dla dywidend między spółkami, pominięto przypadki, gdy dywidenda wypłacana jest zagranicznym wspólnikom będącym osobami fizycznymi.

6 Zysk zatrzymany wynika z podziału zysku netto wypracowanego $w$ przedsiębiorstwie $w$ danym roku obrotowym na część wypłaconą właścicielom i część, która jest zatrzymana w celu reinwestycji. Akumulacja kapitału jest pewnym przybliżeniem tej kategorii, a dla uproszczenia zdefiniowano ją jako różnicę między osiągniętym zyskiem netto a wypłaconą dywidendą na rzecz akcjonariuszy.

Przy rozszerzeniu metody na spółki niegiełdowe może pojawić się trudność z ujawnieniem akcjonariatu.
}

nicznych często są rezydenci krajowi unikający opodatkowania. W przypadku podziału zysku i wypłaty dywidendy spółkom z siedzibą za granicą nie przyznano punktacji.

Niestety, nie da się w pełni ocenić sytuacji, gdy akcjonariusze mają mniej niż 5\% akcji ${ }^{8}$ i stwierdzić, czy przeznaczenie analizowanego zysku można uznać za sytuację b) czy c). Przyjęto, że akcjonariuszami są podmioty z siedzibą w Polsce lub osoby fizyczne będące rezydentami krajowymi.

\section{Zastosowanie oceny na przykładzie wybranych spółek giełdowych}

W tym punkcie zastosowano proponowaną metodę do oceny trzech spółek, których sprawozdania finansowe pozwalają na jej dokonanie za lata 2015-2017. Są to: Grupa Żywiec S.A., Wawel S.A. oraz NEWAG S.A. Podsumowania dokonano $w$ tabeli 1.

\subsection{Wawel S.A.}

Wawel S.A. to jedna z najstarszych fabryk cukierniczych w Polsce. Hosta Intl. AG z siedzibą w Szwajcarii posiada 52,13\% ogólnej liczby akcji. Ze sprawozdań spółki wynika, że na koniec 2017 r. 14,89\% akcji należało do OFE, a $32,98 \%$ do pozostałych akcjonariuszy. Stosując przyjętą metodę obliczono punktację dla przedsiębiorstwa obrazującą skalę korzyści, którą jego działalność przynosi krajowej gospodarce. W relacji do aktywów w 2017 r. (patrz tabela 1):

a) wynagrodzenia wyniosły $10,7 \%$,

b) podatek dochodowy wyniósł $2,8 \%$,

c) akumulacja kapitału wyniosła 10,7\%,

d) dywidenda na rzecz rezydentów krajowych wyniosła 2,1\% (w przypadku 100\% akcjonariatu krajowego punktacja zwiększyłaby się o 2,3 pkt proc.).

Łącznie w relacji do aktywów spółka wygenerowała 26,3\% krajowej wartości dodanej.

\footnotetext{
Akcje spółek publicznych są przedmiotem ciągłego obrotu, dlatego prawo przewiduje obowiązek ujawnienia tylko takich akcjonariuszy, którzy posiadają pow. 5\% akcji.
} 


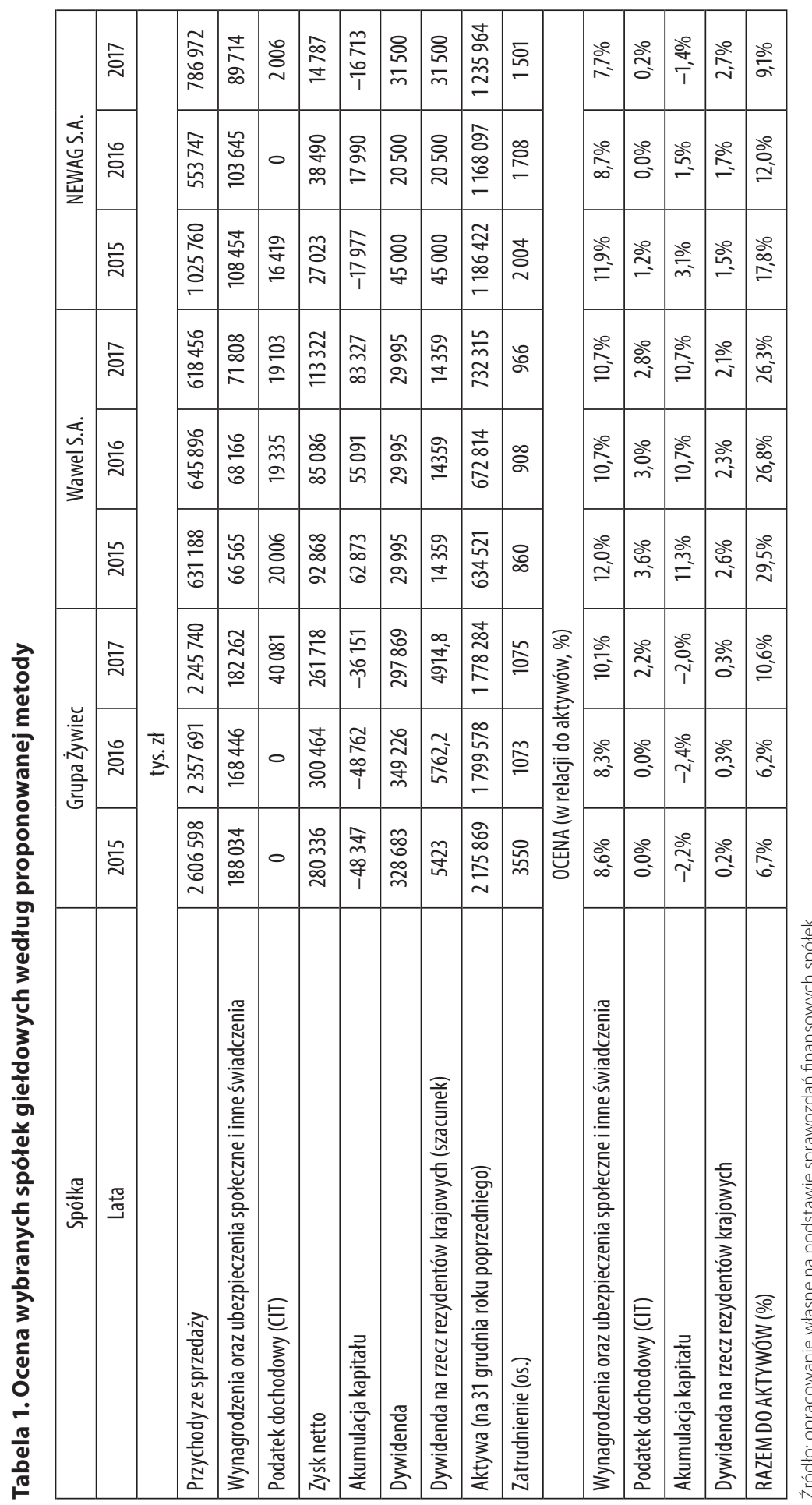




\subsection{Grupa Żywiec S.A.}

Podstawowym segmentem działalności Grupy Żywiec ${ }^{9}$ jest produkcja piwa, jego dystrybucja, a także dystrybucja innych napojów alkoholowych i bezalkoholowych. Akcjonariat Grupy Żywiec SA wg stanu na 31 grudnia 2017 r. stanowią dwa główne podmioty: Heineken International B.V. posiadający $65,16 \%$ akcji Grupy oraz Harbin B.V. posiadający 33,19\% akcji. Do akcjonariuszy krajowych mogło należeć maksymalnie 1,65\% akcji. Stosując przyjętą metodę obliczono punktację dla przedsiębiorstwa obrazującą skalę korzyści, którą jego działalność przynosi krajowej gospodarce. W relacji do aktywów w 2017 r. (patrz tabela 1):

a) wynagrodzenia wyniosły $10,1 \%$,

b) podatek dochodowy wyniósł $2,2 \%$,

c) akumulacja kapitału wyniosła (-)2,2\% (przedsiębiorstwo zmniejszyło swój majątek, gdyż dywidenda wypłacona właścicielom przewyższyła zysk),

d) dywidenda na rzecz rezydentów krajowych wyniosła 0,3\% (w przypadku 100\% akcjonariatu krajowego punktacja zwiększyłaby się o 16,3 pkt proc.).

Łącznie w relacji do aktywów spółka wygenerowała 10,7\% krajowej wartości dodanej.

\subsection{NEWAG S.A.}

NEWAG to spółka z tradycjami sięgającymi XIX w. Spółka ma doświadczenie w modernizacji i produkcji taboru kolejowego, tramwajów i pojazdów metra. Akcjonariat NEWAG S.A. wg stanu na 31 grudnia 2017 r. obejmuje: 42,57\% akcji Jakubas Investments sp. z o.o., $18,85 \%$ akcji trzech OFE oraz 38,58\% akcji pozostałych akcjonariuszy. Tak jak w poprzednich latach struktura ta sugeruje zaklasyfikowanie wszystkich z nich jako krajowych.

Stosując przyjętą metodę obliczono punktację dla przedsiębiorstwa obrazującą skalę korzyści, którą jego działalność przynosi krajo-

9 Tradycje browaru sięgają XIX w. Pierwotnym właścicielom - polskiej gałęzi rodziny Habsburgów, został on odebrany w 1939 r. przez III Rzeszę, a w 1944 r. przejęty przez Skarb Państwa na mocy dekretu o reformie rolnej. wej gospodarce. W relacji do aktywów w 2017 r. (patrz tabela 1):

a) wynagrodzenia wyniosły $7,7 \%$,

b) podatek dochodowy wyniósł 0,2\%,

c) akumulacja kapitału wyniosła (-)1,4\% (przedsiębiorstwo osiągnęło mniejszy zysk niż wypłaciło dywidendy),

d) dywidenda na rzecz rezydentów krajowych wyniosła $2,7 \%$.

Łącznie w relacji do aktywów spółka wygenerowała 9,1\% krajowej wartości dodanej.

\section{Wnioski i kierunki dalszych badań}

Zastosowanie metody w praktyce na trzech wybranych spółkach giełdowych pozwala sformułować wnioski, które zostaną uwzględnione przy poddaniu ocenie kolejnych spółek:

- Podziałakcjonariuszy na rezydentów krajowych i zagranicznych pozwala potwierdzić przypuszczenie, że narodowość akcjonariuszy nie przesądza o wartości korzyści, które przedsiębiorstwo przynosi gospodarce krajowej - choć poprzez wypłatę dużej dywidendy za granicę może je znacząco zmniejszyć.

- Akumulacja kapitału zwiększa jednocześnie aktywa przedsiębiorstwa, co każe rozważyć, na ile aktywa mogą być dobrym punktem odniesienia dla sumy korzyści.

- Wahania wartości oceny w czasie kształtowane są przez jednorazowe wydarzenia gospodarcze - dla stabilizacji oceny należy rozważyć zastosowanie kilkuletniej średniej.

- Do proponowanej metody można wprowadzić kryteria dodatkowe, po przetestowaniu metody podstawowej na większej grupie przedsiębiorstw. Rozważając ewentualne rozszerzenia należałoby ocenić zgodność nowego elementu z korzyścią dla gospodarki, której istotę należy uchwycić i dostępność danych. W szczególności rozważyć należy ocenę skali działalności innowacyjnej przedsiębiorstw, działania z zakresu społecznej odpowiedzialności biznesu (CSR) oraz ewentualne zmniej- 
szenie punktacji w przypadku pomocy publicznej.

\section{Literatura}

Begg, D., Vernasca G., Fischer S., Dornbusch R. (2014). Makroekonomia. Warszawa: Wydawnictwo Naukowe PWN.

Bess R., Ambargis Z. (2011). Input Output Models for Impact Analysis: Suggestions for Practitioners Using RIMS II Multipliers. Referat zaprezentowany podczas The 50th Southern Regional Science Association Conference, Louisiana.

Białowąs T. (2016). "Zmiany strukturalne a wzrost gospodarczy krajów Europy Środkowej", Rocznik Instytutu Europy Środkowo-Wschodniej, z. 5, s. 121-139.

Blanchard O. (2011). Makroekonomia. Warszawa: Oficyna Wolters Kluwers business.

Głowacki J., Jelonek M. (2013). Badanie społecznej wartości dodanej podmiotów ekonomii społecznej w Polsce za pomoca narzędzia ESometr: raport z badania. Kraków: Małopolska Szkoła Administracji Publicznej Uniwersytetu Ekonomicznego.

Hamilton J.R., Whittlesey N.K., Robison M.H., Ellis J. (1991). "Economic Impacts, Value Added, and Benefits in Regional Project Analysis", American Journal of Agricultural Economics, Vol. 73, No. 2, s. 334-344.

Kuznets S. (1934). National Income, 1929-1932. 73rd US Congress, $2 \mathrm{~d}$ session, Senate document no. 124, s. $5-7$.
Leontief W. (1941). The structure of the American economy. Cambridge, Massachusetts: Harvard University Press.

Lequiller F., Blades D. (2006). Understanding National Accounts. Paris: OECD.

Lorenc S. (2016). "Metodologie raportowania wartości dodanej dla interesariuszy", Organizacja i zarzadzanie. Kwartalnik naukowy Politechniki Śląskiej, nr 2(34), s. 127-141.

Miller R.E., Blair P.D. (2009). Input-Output Analysis: Foundations and Extensions. 2nd ed. New York: Cambridge University Press.

Nowicki D. (2018). „Ekonomiczna wartość dodana jako narządzie oceny dokonań przedsiębiorstwa", Studia Ekonomiczne. Zeszyty Naukowe Uniwersytetu Ekonomicznego w Katowicach, nr 347, s. 134-144.

Wawiernia A. (2013). „Warunki tworzenia wartości dodanej w przedsiębiorstwie", Zeszyty Naukowe Uniwersytetu Szczecińskiego. Finanse, Rynki Finansowe, Ubezpieczenia, nr 64, T. 1, Zarządzanie wartością przedsiębiorstwa, s. 287-294.

WBCSD (2013). Measuring socio-economic impact, A guide for business. World Business Council for Sustainable Development, www.wbcsd.org (dostęp: 29.12.2015)

Weisbrod B, Weisbrod G. (1997). Measuring Economic Impacts of Projects and Programs. Economic Development Research Group.

\section{Conceptual framework of an assessment of an economic impact of an enterprise}

Summary: In the context of the "middle income trap" discussion and promotion of domestic enterprises, the paper proposes a method aiming at identification and calculation of benefits of national economy that are brought by an enterprise. Research method consists of identification of categories impacting value added created by a firm and of testing such a tool using financial statements of three public companies. Scoring an enterprise bases upon sum of taxes and remuneration of labour and capital, i.e. corporate income tax, salaries and other benefits of employees, as well as capital accumulation together with profit shared among domestic residents. In order to take into account the scale of an enterprise and to measure efficiency of production factors' use, this sum is then divided by firm's assets' value. Conclusions cover the conformation of leaving aside the nationality of firm owners, inquiry into the degree of accuracy in which the method corresponds to the economic reality and potential inclusion of additional criteria of measuring social impact of an enterprise.

Keywords: economic impact of an enterprise, social benefits, value added, profit, taxes, wages. 


\section{Prawa autorskie i licencja / Copyright and License}

Artykuł opublikowano na licencji Creative Commons

Uznanie autorstwa - Użycie niekomercyjne - Bez utworów zależnych 3.0 Polska

http://creativecommons.org/licenses/by-nc-nd/3.0/pl/

This article is published under the terms of the Creative Commons

Attribution - NonCommercial - NoDerivs (CC BY-NGND 3.0) License

http://creativecommons.org/licenses/by-nc-nd/3.0/ 